University for Business and Technology in Kosovo

UBT Knowledge Center

Oct 27th, 10:45 AM - 12:15 PM

\title{
An Initial Key Evaluation of The Strategic Interaction Between Macroeconomic Policies in Albania
}

\author{
Bernard Dosti \\ University of Tirana, bernarddosti@feut.edu.al \\ Elena Polo \\ University of Tirana, polo_elena@hotmail.com
}

Follow this and additional works at: https://knowledgecenter.ubt-uni.net/conference

Part of the Business Commons

\section{Recommended Citation}

Dosti, Bernard and Polo, Elena, "An Initial Key Evaluation of The Strategic Interaction Between Macroeconomic Policies in Albania" (2018). UBT International Conference. 279.

https://knowledgecenter.ubt-uni.net/conference/2018/all-events/279

This Event is brought to you for free and open access by the Publication and Journals at UBT Knowledge Center. It has been accepted for inclusion in UBT International Conference by an authorized administrator of UBT Knowledge Center. For more information, please contact knowledge.center@ubt-uni.net. 


\title{
An initial key evaluation of the strategic interaction between macroeconomic policies in Albania
}

\author{
Bernard DOSTI ${ }^{1}$, Elena POLO ${ }^{2}$ \\ ${ }^{1}$ University of Tirana, Faculty of Economy, Department of Economics \\ ${ }^{2}$ University of Tirana, Institute of European Studies
}

\begin{abstract}
Monetary and fiscal policy constitutes principal macro-policies, even though they are usually designed and implemented with quite different sometimes even contrary - goals. Although they have a certain degree of independence mostly in the institutional basis, there is also a considerable level of interdependence between them. This one is usually found in the literature with the term "interaction" and then "harmonization" when the country operates within a monetary union. The first objective of this paper is to shortly identify main elements of the interaction between macro-policies. The second objective is to evaluate this mutual interaction among them for the Albanian case with historical data using each policy reaction function in a non-simultaneous way. Related to the methodology, there will be a descriptive comparative analysis of various economic variables indicating ways of interaction between monetary and fiscal policy also with revisiting their instruments and coordination after the crisis. Following this theoretical approach, there will be an evaluation on the mutual interaction, where the methodological approach of the latter relates to game theory generally analyzing decision situations. The first results of this work relate to the stabilizing effects of monetary and fiscal policy. The other results will rely on the changes of one policy as a response of changes in the other. If this one is statistically approved, we can confirm a presence of strategic interaction between the two macro-policies. All above mentioned elements will shed light on some first theoretical and empirical findings for Albania contributing to a further research debate and work in the field.
\end{abstract}

Keywords: macro-policies, policy objectives, interaction, policy reaction functions

\section{Introduction}

The last crisis indicated that macroeconomic policies must have more objectives and more instruments when implemented, but the exact answer to the question which instrument should be directed towards achieving specific economic policy goals requires time. In general terms, the economic crisis restored the central role of fiscal policy right after the recognition that monetary policy had reached its limit [17]. Furthermore, it changed the way of understanding on strategies, effects, roles of the authorities of monetary and fiscal policies. 
Furthermore, research has shown that there is a kind of relationship between changes in monetary and fiscal policies and the large need for stabilizing the economy through given instruments and the new concept of policy space. As a result of the crisis, macroeconomic policies would partly change in some of their elements for almost all economies. In the meanwhile, credibility in designing and implementing policies will support their overall effectiveness. Last but not least, there is a need to jointly analyze macroeconomic policies through an interaction approach as an appropriate tool of analysis for the complex real economies.

Scope of this paper is to identify and describe main elements of the interaction between the two macroeconomic policies as well as tools of the analysis of the interaction approach in a theoretical and empirical basis developed in the literature of the field. There will be an evaluation on the mutual interaction of the policies, with the methodological approach of the latter relating to game theory widely used in analyzing decision situations.

The paper will be organized as given below: a brief summary of main research works in the field of macroeconomic policies for recent instruments and interaction issues, with a larger focus on the game theory tools of analysis; a theoretical and empirical evaluation of a model with selected macroeconomic indicators and instruments in the game theory context, resulting in some conclusions and restrictions of this analysis for the Albanian case.

\section{Literature review}

Both policies can and must be designed and implemented with the aim to amortize large fluctuations in the economy [18]. By the other side, there are some crucial points in implementation as issues of any compliance in the objectives of the policies, an efficient information exchange among respective authorities and a sustainable or a coherent behavior in time in order to ensure for higher positive effects of macro policies.

For all economies, an efficient management of the economy depends on the level of the understanding of internal shocks and their reciprocal effects. Fiscal and monetary policy with their changes interact through several and complex transmission channels. Monetary policy affects budget policy through the so-called seigniorage; inflation rate as a monetary instrument or phenomenon affects level of real public debt; fiscal discipline has an impact on the monetary authority and its public credibility; fiscal policy and unexpected inflation affect employment level, as a key macroeconomic objective of policy interaction. Other similar impacts can also be mentioned in this context.

Additionally, even though in the very beginning EMU believed the monetary union could operate without a fiscal one, nowadays there is a totally different view with numerous studies of analyzing policies in this context. So, in some European countries, fiscal behavior is not consistent with having the ECB target inflation. Such inconsistencies can have further implications for inflation, interest rates and macroeconomic performance. Meanwhile even the conventional view underlies how 
countries have designed central banks, but fiscal policy must cooperate and behave consistently.

According to IMF analysis in 2013[14], central banks must be envisaged to have a broader macro and financial stability mandate, using monetary and macro prudential instruments while more actively using fiscal policy tools. The interaction between macro policies affects though the stabilizing process in the economy, with a sound fiscal policy providing room for an active monetary policy together with studying the reactions of the two macro policies to inflation, output gap, interest rate and debt stabilization.

Walsh (2003)[20] first started with analyzing fiscal policy including also instruments of the monetary policy. Laubach (2009) and De Mello (2005)[16], 9] have both analyzed that idea during a recession, when reducing short-term interest rates results in reduced long-term interest rates parallel with increasing budget deficit because of the automatic stabilizers. In this context one important finding is the identification of any potential negative correlation between budget deficit and shortterm interest rates.

Related to policy objectives, there is an output conservatism of fiscal and monetary authorities, both operating with smoothing policy instruments. According to Aktas et al., (2009)[2], fiscal dynamics play a very important role in the effectiveness of monetary policy. By the other side, monetary policy can limit fiscal policy in rather different ways depending on whether accepting the stabilizing reevaluations of government debt [19]. Anyway, a conservative monetary policy remains desirable in all cases of specific economic conditions, especially when fiscal policy is determined first and monetary authority should explicitly be focused on the inflation stabilizing. To conclude with this idea, the best results in the objective functions are achieved by the cooperative Pareto solution supporting a more active role of the central bank.

Welfare is higher under fully optimal policies than under divided policies and this can be used as a call for rethinking our policy institution arrangements (Leeper, 2014). What advanced economies have done consist in keeping interest rates low for a long period of time to re-inflate their economies. But, running the non-right fiscal policies absolutely cannot help in this aspect. Once again, this emphasizes the need to start and jointly think about monetary and fiscal policy.

To conclude with this theoretical approach, it is true that macro policies are about what set of rules authorities follow, what are the public expectations about and what institutions represent. For sure, the structure of the policy is the right answer, but treating monetary and fiscal policy as completely independent misrepresents macroeconomic reality. Any attempts for cooperation and consistency between the two important macro policies is desirable for all economies.

\section{Theoretical and empirical basis for the game theory context}

Main assumption of this type of analysis is that when achieving goals of both policies, there are several issues to be taken into consideration as other macroeconomic indicators, impacts of their decisions and the behavior or reaction of the other economic policy authority. As long as several situations may happen, game 
theory context is the appropriate method to study such quite different scenarios. With ensured respective independence, the central bank is focused on stabilizing inflation through interest rates while fiscal authority aims to stabilize budget through fiscal deficit.

Below is given the specification model for the fiscal authority. Main instrument of the policy can change as a function of changes in other important macroeconomic indicators and specifically the change in the main instrument of the other policy. For the fiscal policy, a possible reaction function can be:

\section{$\Delta$ primbalancet $=\alpha 0+\alpha 1 \Delta$ govdebtt-1 $+\alpha 2 \mathrm{Eyt}+\alpha 3$ primbalancet-1 $+\alpha 4 \mathrm{ut}+$} $\alpha 5 \Delta \mathrm{it}+\mathbf{\varepsilon t}$,

With primary balance as a $\%$ of the GDP, government debt in absolute value, Eyt for the output gap, ut for the unemployment rate and it for the short-term interest rates, representing monetary policy.

\section{Results}

There are given below the results from the OLS regression using the fiscal policy reaction function with quarterly data for the period 2007-2017. Secondary data for the macroeconomic indicators are taken from the Institute of Statistics, Ministry of Finance and Bank of Albania database and reports.

Table 1: The reaction function of the fiscal policy

\begin{tabular}{|c|c|c|c|c|c|c|c|}
\hline source & ss & $d f$ & & is & & $\begin{array}{l}\text { Number of obs } \\
\text { F( 4, } 30)\end{array}$ & $\begin{array}{r}35 \\
2.02\end{array}$ \\
\hline Model & .000530783 & 4 & .00 & 2696 & & & $\begin{array}{r}2.02 \\
0.1169\end{array}$ \\
\hline Residual & .001970841 & 30 & .00 & 5695 & & R-squared & 0.2122 \\
\hline & & & & & & Adj R-squared & 0.1071 \\
\hline Total & .002501625 & 34 & .00 & 3577 & & Root MSE & .00811 \\
\hline fdprimbala e & Coef. & std. & Err. & t & $P>|t|$ & [95\% Conf. & Interval] \\
\hline fdlgovdebt & $-2.39 e-07$ & $2.00 e$ & -07 & -1.20 & 0.241 & $-6.47 e-07$ & $1.69 e-07$ \\
\hline lprimbalance & -.2407846 & .0967 & 961 & -2.49 & 0.019 & -.4384685 & -.0431006 \\
\hline unemployment & -.0004861 & .0009 & 283 & -0.52 & 0.604 & -.002382 & .0014098 \\
\hline fdinterest & .0146201 & .0088 & 044 & 1.66 & 0.107 & -.0033608 & .032601 \\
\hline _cons & .0095605 & .0139 & 653 & 0.68 & 0.499 & -.0189604 & .0380815 \\
\hline
\end{tabular}

Source: Authors calculations

From the above estimation, the only variable statistically significant is that of the lagged primary balance as a percentage to the GDP, at a $10 \%$ of significance. There is a negative relation for this variable, which implies for an adoptive fiscal policy to the previous period. For the change in interest rates, which is quasi-significant, there is a positive relation indicating for a possible coordination with monetary policy. Although not statistically significant, unemployment and change in the lagged government debt are represented with negative coefficients which means that the government is not focused on reducing public debt in absolute terms and conducts an expansive fiscal policy during periods with increasing unemployment rate. 
When compared to the expectations, the only variable with an opposite effect in the change of the main instrument of the fiscal policy is that of the change in the prior levels of absolute public debt. We can assume that during the period 2007-2017, fiscal policy seems to be not seriously committed to the fiscal consolidation and its outcomes. The other variables have the signs in interpretation as expected based on the theory and other tools of analysis.

Table 2: The reaction function of the fiscal policy

\begin{tabular}{|c|c|c|}
\hline Variable & Expected relation & Factual relation \\
\hline Sgovdebt $_{t-1}$ & + & - \\
\hline primbalance $_{t-1}$ & - & - \\
\hline $\boldsymbol{u}_{\boldsymbol{t}}$ & - & - \\
\hline$\Delta \boldsymbol{i}_{t}$ & $+/$ - (coordination/conflict) & + \\
\hline
\end{tabular}

Source: Authors calculations

These results using OLS regressions can be accepted and though interpreted with the respective signs, coefficient values and statistical significance. Anyway, models of SEM (simultaneous equations) can be more appropriate, as all included important macroeconomic indicators can be tested as dependent and independent with a set of different equations, which is quite complex in the same time.

In the case of Albania, as a restriction for this model can be mentioned the quality of the macroeconomic indicators especially when used in quarterly data. For the model presented in this paper, we have not included "output gap" as a variable, indicating for restrictive macroeconomic policies when positive (actual product above the potential level) as analyzed by Kappel and Janku, 2014[15]. In the case of having the reaction functions for the two macroeconomic policies, we can also conclude for dominant roles in the game theory context when assuming for coordinated decisions.

\section{Conclusions}

For the Albanian economy, determining the dependence of both policies on the changing macroeconomic environment, on the extent of fulfilling their policy objectives as well as on the behavior of the other policy remain a very interesting and crucial point. For all the economies, jointly analyzing fiscal and monetary policy with their specific behavior and interaction seems to be more interesting and efficient tool of analysis in the current macroeconomic field.

Even the simplest models indicate for a level of interaction and coordination between the two macroeconomic policies. In the same time, improving quality of the macroeconomic indicators and using more complex specification models will help in advancing research in this context with theoretical and empirical findings for Albania. 


\section{References}

1. Ahrend, R., Pietro, A., and Price, R., (2007), Interactions between Monetary and Fiscal Policy: How Monetary Conditions Affect Fiscal Consolidation, OECD Economics Working Paper No. 2006/49

2. Aktas, Z., Kaya, N., and Ozlale, U., (2009), Coordination between monetary and fiscal policy for an inflation targeting emerging market, Journal of International Money and Finance, No. 29

3. Balboni, F., Buti, M., and Larch, M., (2007), Monetary and fiscal policy interactions in the EMU when cyclical conditions are uncertain, European Economy Economic Papers No. 277

4. Beetsma, R. M. W. J., and Bovenberg, L. A., (1998), Monetary union without fiscal policy coordination may discipline policymakers, Journal of International Economics, $45(2)$

5. Blueschke, D., and Neck, R., (2015), Optimal macro policies in a monetary union: a dynamic game

6. Cebi, C., (2012), The interaction between monetary and fiscal policy in Turkey: an estimated New Keynesian DSGE model

7. Clarida, R., Gali, J., and Gertler, M., (1998), Monetary policy rules in practice: Some international evidence, European Economic Review. 42 (6)

8. Dell'Ariccia, B., and Mauro, (2013), Rethinking macroeconomic policies 2: getting granular, IMF staff discussion notes

9. De Mello, L., (2005), "Estimating a fiscal reaction function: the case of debt sustainability in Brazil", OECD Economics Department, Working Paper No. 43

10. Diaz-Roldan, C., and Monteagudo-Cuerva, C., (2013), Fiscal policy under alternative monetary policy regimes

11. Dixit, A., and Lambertini, L., (2003), Interactions of commitment and discretion in monetary and fiscal policies, The American Economic Review, 93 (5)

12. Gaspar, V., (2015), How does fiscal policy affect growth and stability?, World Economic Forum

13. Huixin, B., Leeper, E.M., and Leith, C., (2012), Uncertain Fiscal Consolidations, NBER Working Paper No. 17844

14. IMF, (2013), The Interaction of Monetary and Macroprudential Policies, Policy papers

15. Kappel, S., and Janku, J., (2014), Integration of monetary and fiscal policy of the countries of Visegrad, Review of Economic Perspectives, Vol.14, Issue 3

16. Laubach, Th., (2009), "New evidence on the interest rate effects of budget deficits and debt", European Economic Association, Vol. 7, No. 4, pp: 858-885

17. Sehovic, D., (2015), The Impact of the Great Recession on Monetary and Fiscal Policy in Developed Market Economies, Business Systems Research, Vol. 6, No. 1

18. Sprinkel, B.W. Role of monetary-fiscal policies, Farm Foundation, Increasing Understanding of Public Problems and Policies, 1963

19. Von Thadden, L., (2004), Active monetary policy, passive fiscal policy and the value of public debt: some further monetarist arithmetic, Journal of Macroeconomics, Vol. 26, Issue 2, 223-25

20. Walsh, C.E., (2003), Monetary Theory and Policy. Cambridge, Massachusetts: The MIT Press,

21. Wyplosz, Ch., (1999), Economic Policy Coordination in EMU: Strategies and institutions, financial supervision and policy coordination in the EMU, ZEI Policy Paper Appendix: Springer-Author Discount 